\title{
EFEKTIVITAS PEMUNGUTAN PAJAK KENDARAAN BERMOTOR DAN BEA BALIK NAMA KENDARAAN BERMOTOR DI BP2RD PROVINSI SULAWESI UTARA
}

\author{
Yuli Erithrina \\ Leonardus Ricky Rengkung \\ Charles R. Ngangi
}

\begin{abstract}
This study aims to see the effectiveness and performance of Motor Vehicle Taxation (PKB) and Motor Vehicle Tranfer of Ownership Fee (BBNKB) in BP2RD North Sulawesi Province. The study was conducted at Samsat Office of North Sulawesi Province. The study period lasted from October 2017 to March 2018. This research used qualitative method through primary data and secondary data. Sampling is done used purposive sampling method. Data collection was done by observation, interview, and documentation study. The data obtained were analyzed using descriptive analysis. The result of the research shows that (1) the effectiveness of motor vehicle taxation and motor vehicle refund in BP2RD North Sulawesi Province is very effective so as to increase Pendapatan Asli Daerah (PAD) of North Sulawesi Province. This can be seen from the calculation of each type of provincial tax with an average percentage above $100 \%$. (2) The performance of motor vehicle taxes and the transfer of motor vehicle name at the Regional Tax and Retribution Board (BP2RD) of North Sulawesi Province, shows very well as the realization exceed the specified target.
\end{abstract}

Keywords: effectiveness, performance, Motor Vehicle Tax (PKB), Motor Vehicle Transfer of Ownership Fee (BBNKB), Agency of Regional Tax and Retribution (BP2RD), North Sulawesi Province

\begin{abstract}
ABSTRAK
Penelitian ini bertujuan untuk melihat keefektifan dan kinerja pemungutan Pajak Kendaraan Bermotor (PKB) dan Bea Balik Nama Kendaraan Bermotor (BBNKB) di Badan Pengelolaan Pajak dan Retribusi Daerah (BP2RD) Provinsi Sulawesi Utara. Penelitian dilakukan di Kantor Samsat Provinsi Sulawesi Utara. Waktu penelitian berlangsung sejak bulan Oktober 2017 hingga Maret 2018. Penelitian ini menggunakan metode kualitatif melalui data primer dan data sekunder. Pengambilan sampel dilakukan secara sengaja (purposive sampling method), yaitu teknik penentuan sampel dengan pertimbangan tertentu. Pengumpulan data dilakukan dengan tahapan observasi, wawancara, dan studi dokumentasi. Data yang diperoleh dianalisis menggunakan analisis deskriptif. Hasil penelitian menunjukkan bahwa (1) Efektivitas pemungutan pajak kendaraan bermotor dan bea balik nama kendaraan bermotor di BP2RD Provinsi Sulawesi Utara adalah sangat efektif sehingga dapat meningkatkan Pendapatan Asli Daerah (PAD) Provinsi Sulawesi Utara. Hal ini dapat dilihat dari perhitungan masing-masing jenis pajak daerah provinsi dengan rata-rata persentase di atas $100 \%$. (2) Kinerja dari pemungutan pajak kendaraan bermotor dan bea balik nama kendaraan bermotor di BP2RD Provinsi Sulawesi Utara, menunjukkan sangat baik karena realisasinya melebihi target yang sudah ditentukan sebelumnya.
\end{abstract}

Kata kunci: efektivitas, kinerja, Pajak Kendaraan Bermotor (PKB), Bea Balik Nama Kendaraan Bermotor (BBNKB), Badan Pengelolaan Pajak dan Retribusi Daerah (BP2RD), Sulawesi Utara 


\section{PENDAHULUAN}

\section{Latar Belakang}

Negara Kesatuan Republik Indonesia dibagi atas beberapa daerah provinsi yang terdiri dari daerah kabupaten dan kota. Setiap daerah tersebut memiliki hak dan kewajiban untuk mengatur dan mengurus sendiri urusan Pemerintahannya dalam rangka meningkatkan penyelenggaraan dan pelayanan kepada masyarakat dimana dalam era otonomi daerah saat ini pemerintah daerah membutuhkan dana yang cukup besar untuk pembiayaannya. Daerah berhak mengenakan pungutan biaya kepada masyarakat berupa pajak. Pemerintah daerah perlu meningkatkan sumber-sumber

penerimaan daerah untuk memenuhi pembiayaan pemerintah dalam melaksanakan pembangunan daerah melalui Pendapatan Asli Daerah (PAD) yang merupakan sumber penerimaan daerah.

Menurut Lembaga Pemungutannya, pajak dibagi menjadi dua yaitu Pajak Negara (Pajak Pusat) dan Pajak Daerah. a) Pajak Negara (Pajak Pusat). Pajak yang dipungut oleh Pemerintah Pusat yang penyelenggaraannya dilaksanakan oleh Departemen Keuangan dan hasilnya akan digunakan untuk pembiayaan Rumah Tangga Negara pada umunya. 1) Pajak yang dipungut oleh Dirjen Pajak adalah Pajak Pengahsilan (PPH), Pajak Pertambahan Nilai (PPN), Pajak Bumi dan Bangunan (PBB), Bea Meterai, Bea Lelang; 2) Pajak yang dipungut oleh Bea Cukai (Dirjen Bea Cukai). b) Pajak Daerah. Pajak daerah adalah pajak-pajak yang

dipungut oleh Daerah Provinsi, Kabupaten/Kota, pemungutanya berdasarkan pada Peraturan Daerah masing-masing dan hasilnya digunakan untuk pembiayaan Rumah Tangga Daerah masing-masing (Juniati, 2013).

Beberapa sumber penerimaan daerah menurut UU No. 32 Tahun 2004 terdiri dari Pendapatan Asli Daerah (PAD), Dana perimbangan dan Lain-lain pendapatan yang sah. Pajak daerah merupakan komponen penting dalam PAD yang harus dikembangkan karena kontribusi yang diberikan terhadap pendapatan asli daerah cukup besar. Salah satu jenis pajak daerah yang merupakan sumber pendapatan daerah terbesar dari sekian jenis pajak yaitu Pajak Kendaraan Bermotor dan Bea Balik Nama Kendaraan Bermotor sebagaimana jenis pajak ini merupakan Pajak Daerah yang berperan penting terhadap pertumbuhan penerimaan daerah. Hal ini terjadi karena setiap tahunnya disetiap daerah terjadi peningkatan yang begitu pesat terhadap pengguna kendaraan bermotor, baik itu kendaraan roda empat maupun roda dua. Peningkatan jumlah kendaraan bermotor yang saat ini berkembang pesat, dapat dilihat berdasarkan data dari Dinas Pendapatan Daerah Provinsi Sulawesi Utara yang menunjukkan jumlah kendaraan bermotor di Sulawesi Utara hingga bulan Oktober 2014 mencapai 283.687 unit. Kendaraan yang membayar Pajak Kendaraan Bermotor sampai dengan September 2014 berkisar 251.516 unit. Seiring dengan pertambahan penduduk setiap tahun, menyebabkan meningkatnya ketergantungan terhadap kebutuhan akan alat transportasi seperti kendaraan bermotor baik roda empat maupun roda dua. Hal tersebut didukung pula dengan berbagai kemudahan yang diberikan dealer dalam pembelian kendaraan bermotor sehingga masyarakat tertarik untuk memilikinya dan selera yang berubah-ubah seiring bergantinya zaman akan mengakibatkan mudahnya terjadi perpindahan kepemilikan suatu kendaraan bermotor dan memicu kepada pengenaan Bea Balik Nama Kendaraan Bermotor, serta kurangnya tingkat pengetahuan tentang peraturan dan banyak yang beranggapan bahwa prosedur dalam pembayaran Bea Balik Nama Kendaraan Bermotor yang rumit dan memerlukan waktu lama. Berdasarkan Perda Nomor 7 Tahun 2011 tentang Pajak Daerah dan Retribusi Daerah, Dinas Pendapatan Daerah akan menerapkan pajak Progresif untuk pembayaran pajak kendaraan bermotor lebih dari satu. Pemerintah daerah memberikan kebijakan berdasarkan Undang-Undang Nomor 28 Tahun 2009, dimana dalam Undang-Undang ini pemerintah daerah akan mendapatkan pemasukan kas daerah melalui pemungutan Pajak Kendaraan Bermotor dan Bea Balik Nama Kendaraan Bermotor untuk meningkatkan penerimaan Pendapatan Asli Daerah.

Efektivitas dalam kontes ini berkaitan dengan kemampuan melakukan atau memilih 
sesuatu yanga dapat memberikan keuntungan sesuai dengan sasaran yang telah ditetapkan. Memiliki kinerja efektif, jika setiap komponen yang ada didalamnya mampu bekerja sama untuk melakukan program yang telah ditetapkan. Menurut Ekvall dan Arvonen (1994), sebuah yang tidak terkoordinasi secara baik, tidak akan mampu mencapai efektivitas yang berbeda.

\section{Pajak Kendaraan Bermotor adalah pajak}

atas kepemilikan dan/atau penguasaan kendaraan bermotor dan pengertian Bea Balik Nama Kendaraan Bermotor adalah pajak atas penyerahan hak milik kendaraan bermotor sebagai akibat perjanjian dua pihak atau perbuatan sepihak atau keadaan yang terjadi karena jual beli, tukar menukar, hibah, warisan, atau pemasukan ke dalam badan usaha (UU NO 28 Tahun 2009). Pemungutan Pajak Kendaraan Bermotor dan Bea Balik Nama Kendaraan Bermotor merupakan jenis pemungutan yang sudah lama dilakukan oleh pemerintah. Pajak ini sangat berpengaruh terhadap sumber Pendapatan Asli Daerah, yang berguna untuk membiayai pelaksanaan tugas rutin pemerintah daerah. Pembangunan daerah tiap kabupaten/kota salah satunya dibiayai dari dana yang didapatkan melalui pajak kendaraan bermotor.

Kebijakan pemungutan pajak berdasarkan peraturan daerah diupayakan tidak berbenturan dengan pungutan pusat (pajak maupun bea dan cukai), hal tersebut akan menimbulkan duplikasi pungutan yang pada akhirnya akan

mendistorsi kegiatan perekonomian. Diantisipasinya Undang-Undang Nomor 28 Tahun 2009 tentang Pajak Daerah dan Retribusi Daerah menyatakan bahwa kebijakan pajak daerah dan retribusi daerah dilaksanakan dengan prinsip demokrasi, pemerataan dan keadilan, peran serta masyarakat, dan akuntabilitas dengan memperhatikan potensi daerah.

Pengelolaan Pajak Kendaraan Bermotor dan Bea Balik Nama Kendaraan Bermotor harus dilakukan secara cermat, tepat dan hati-hati. Pemerintah daerah perlu memiliki sistim pengendalian yang memadai untuk menjamin ditaatinya sistim dan prosedur kebijakan manajemen yang telah ditetapkan. Selain itu perlu dilakukan penyederhanaan prosedur administrasi yang bertujuan untuk memberi kemudahan bagi masyarakat membayar pajak sehingga diharapkan dapat meningkatkan kepatuhan membayar pajak, dengan harapan dimasa yang akan datang bisa memperbesar persentase penerimaan daerah. Maka pemungutan penerimaan pajak ini perlu dioptimalkan sebaik mungkin. Kesadaran wajib pajak adalah kondisi dimana wajib pajak

memahami dan melaksanakan aturan perpajakan dengan benar dan sukarela. Apabila pemahaman dan pelaksanaan kewajiban perpajakan semakin baik, maka tingkat kesadaran wajib pajak semakin tinggi sehingga diharapkan dapat meningkatkan kepatuhan perpajakannya (Muliari dan Ery, 2011 dalam Amanda, 2012).

Berkaitan dengan potensi kendaraan bermotor, Badan Pengelola Pajak dan Retribusi Daerah (BP2RD) Provinsi Sulawesi Utara yang merupakan instansi pelaksana di bidang pengelolaan dan koordinator pendapatan daerah untuk dapat menggali dan meningkatkan potensi sumber-sumber pendapatan daerah terutama pendapatan daerah dari pendapatan asli daerah.

Potensi kendaraan bermotor roda 2 dan kendaraan bermotor roda 4 di Provinsi Sulawesi Utara setiap tahunnya mengalami kenaikan. Melihat realita ini, diharapkan penerimaan pendapatan pemerintah yang bersumber dari Pajak Kendaraan Bermotor dan Bea Balik Nama Kendraan Bermotor dapat meningkat sejalan dengan meningkatnya jumlah pembelian kendaraan bermotor karena peranan Pajak Kendaraan Bermotor dan Bea Balik Nama Kendaraan Bermotor kegiatan pemungutan Pajak Kendaraan Bermotor dan Bea Balik Nama Kendaraan Bermotor dapat dikatakan masih belum efektif karena masih ada yang belum mencapai $100 \%$.

Efektivitas menjadi sebuah hal yang sangat penting karena mampu memberikan gambaran mengenai keberhasilan suatu organisasi dalam mencapai sasarannya atau dapat dikatakan bahwa efektivitas merupakan tingkat ketercapaian tujuan dari aktivasi- 
aktivasi yang telah dilaksanakan dibandingkan dengan target yang telah ditetapkan sebelumnya.

Upaya mengevaluasi jalannya suatu organisasi, dapat dilakukan melalui konsep efektivitas. Konsep ini adalah suatu faktor untuk menentukan apakah perlu dilakukan perubahan secara signifikan terhadap bentuk dan manajemen organisasi atau tidak. Dalam hal ini efektivitas merupakan tujuan organisasi melalui pemanfaatan sumber daya yang dimiliki secara efisien.

Oleh karena itu, untuk memecahkan permasalahan tersebut maka diperlukan sebuah kajian yang lebih mendalam guna melihat hal-hal apa saja yang dapat membuat efektif dan tidak efektifnya penerimaan Pajak Kendaraan Bermotor dan Bea Balik Nama Kendaraan Bermotor. Hal ini menjadi tantangan bagi Badan Pengelola Pajak dan Retribusi Daerah untuk mencari strategi apa untuk meningkatkan penerimaan Pajak Kendaraan Bermotor dan Bea Balik Nama Kendaraan Bermotor sehingga bisa mencapai target PAD yang ada.

\section{Rumusan Masalah}

Berdasarkan latar belakang yang telah diuraikan di atas, maka yang menjadi permasalahan penelitian yaitu sebagai berikut:

1. Apakah Efektivitas Pemungutan Pajak Kendaraan Bermotor (PKB) dan Bea Balik Nama Kendaraan Bermotor (BBNKB) di BP2RD Provinsi Sulawesi Utara?

2. Bagaimana kinerja Pemungutan Pajak Kendaraan Bermotor (PKB) dan Bea Balik Nama Kendaraan Bermotor (BBN-KB) di BP2RD Provinsi Sulawesi Utara?

\section{Tujuan Penelitian}

Berdasarkan rumusan masalah tersebut, maka tujuan penelitian ini adalah untuk:

1. Melihat Keefektifan Pemungutan Pajak Kendaraan Bermotor (PKB) dan Bea Balik Nama Kendaraan Bermotor (BBN-KB) di BP2RD Provinsi Sulawesi Utara.

2. Melihat kinerja Pemungutan Pajak Kendaraan Bermotor (PKB) dan Bea Balik Nama Kendaraan Bermotor (BBNKB) di BP2RD Provinsi Sulawesi Utara.

\section{Manfaat Penelitian}

Berdasarkan tujuan penelitian, maka harapan besar penelitian ini dapat memberikan kegunaan sebagai berikut:

1. Secara Praktis

Dapat digunakan oleh BP2RD Provinsi Sulawesi Utara sebagai gambaran yang lebih jelas mengenai tindakan/kebijakan apa saja yang harus diperhatikan dalam meningkatkan PAD dan sebagai bahan masukan bagi BP2RD Provinsi Sulawesi Utara untuk mengevaluasi kebijakan Daerah untuk mengefetifkan dan mengefisienkan

prilaku kinerja pemungutan Pajak Kendaraan Bermotor dan Bea Balik Nama Kendaraan Bermotor (BBNKB) melalui pemahaman Undang-undangn perpajakan.

2. Secara Teoritis

Dapat digunakan sebagai bahan referensi untuk memperluas wawasan ataupun sebagai acuan bagi penelitian yang dilakukan khususnya yang berkaitan dengan penelitian ini yaitu Efektivitas Pemungutan Pajak Kendaraan Bermotor Dan Bea Balik Nama Kendaraan Bermotor di BP2RD Provinsi Sulawesi Utara.

\section{METODE PENELITIAN}

\section{Tempat dan Waktu Penelitian}

Penelitian dilakukan di Kantor Samsat Provinsi Sulawesi Utara. Waktu penelitian berlangsung sejak bulan Oktober 2017 hingga Maret 2018.

\section{Jenis dan Sumber Data}

Penelitian ini menggunakan metode kualitatif. Kualitatif adalah penelitian yang bermaksud untuk memahami fenomena tentang apa yang dialami oleh subjek penelitian. Penelitian kualitatif menggambarkan tanggapan informan terhadap efektivitas penerimaan pajak. Untuk mengetahui tanggapan informan maka peneliti menggunakan pedoman wawancara yang berisi pertanyaan-pertanyaan penelitian.

Sumber data terdiri dari data primer dan data sekunder. Data primer diperoleh langsung dari lapangan melalui informan yang telah ditentukan, sedangkan data sekunder diperoleh dari instansi atau lembaga-lembaga yang terkait 
seperti Badan BP2RD Provinsi Sulawesi Utara, BPS Provinsi Sulawesi Utara, dan institusi terkait lainnya.

Teknik Pengambilan Sampel

Penelitiaan danresponden dilakukan secara sengaja (purposive sampling method), yaitu teknik penentuan sampel dengan

pertimbangan tertentu. Dengan teknik (purposive sampling method) merupakan cara pengambilan sampel yang berdasarkan atas tujuan dan pertimbangan peneliti yang berhubungan dengan Informan yang dianggap memiliki informasi dan mengetahui masalah yaitu individu yang terlibat langsung dalam pemungutan Pajak Kendaraan Bermotor dan Bea Balik Nama Kendaraan Bermotor. Informan yang ikut terlibat dalam penelitian ini, yaitu:

1. Sekretaris Badan BP2RD Provinsi Sulawesi Utara.

2. Kepala Sub Bagian Kepegawaian dan Hukum BP2RD Provinsi Sulawesi Utara.

3. Staf Bidang Pajak Daerah BP2RD Provinsi Sulawesi Utara.

4. Staf Bidang Pajak BP2RD Provinsi Sulawesi Utara.

5. Wajib Pajak.

\section{Fokus Penelitian}

Fokus dari penelitian ini yaitu efektivitas pemungutan Pajak Kendaraan Bermotor dan Bea Balik Nama Kendaraan Bermotor, di mana aspek-aspek utama yang diteliti terdiri dari:

1. Penerimaan Pajak Kendaraan Bermotor Indikatornya: target penerimaan Pajak Kendaraan Bermotor per bulan dan realisasi penerimaan pajak kendaraan bermotor per bulan. Penerimaan Bea Balik Nama Kendaraan Bermotor.

2. Kesadaran masyarakat

Indikatornya: pengetahuan masyarakat mengenai pajak, pemahaman terhadap isi dan aturan untuk membayar pajak, sikap masyarakat dalam membayar pajak.

3. Kepatuhan masyarakat

Indikatornya: ketepatan waktu pelaporan pajak, pembayaran pajak sebelum jatuh tempo.

\section{Teknik Pengumpulan Data}

Pengumpulan data dalam dalam penelitian ini dilakukan dalam tiga tahapan yaitu:

1. Observasi

Peneliti mengadakan observasi di lokasi tempat penelitian untuk menemukan data dan fakta yang ada dilapangan oleh sebab itu peneliti berorientasi dengan lingkungan, sosial dan budaya ditempat dimana penelitian itu dilakukan untuk melihat fakta yang apa yang terjadi dan mendegar apa yang diikatakan oleh orangorang yang ada dilokasi penelitian.

Dalam hal penelitian ini peneliti mengadakan observasi berhubungan dengan fokus penelitian dengan tahapan sebagai berikut:

a. Mendiskripsi hasil pengamatan Hal-hal umum dan faktual dalam fokus

penelitian ini dideskripsi baik kemampuan sumber daya manusia, ketenagaan, bentuk kelembagaan dan sarana serta dana dan fasilitas lain dalam menunjang program pemungutan pajak kendaraan dan bea balik nama kendaraan bermotor khususnya sub sistem pencatatan pelaporan

b. Observasi Terfokus

Mengadakan pengamattan secara terarah intensif dan terfokus pada pemasalahan yang terjadi dalam pengolaan sistem pencatattan dan pelaporan mulai dari segi pengetahuuan dan kemampuan.

2. Wawancara

Dalam penelitian kualiitatif observasi saja tidak memadai atau belum cukup untuk melakukan penelitian. Untuk itu perlu diadakan komunikasi lewat wawancara untuk mendapatkan inormasi secara langsung dari responden dan untuk mengetahui apa yang dirasakan orang lain.

Langkah-langkah yang di tempuh oleh peneliti ini yaitu menggunakan teknik wawancara menurut Lincoln dan Guba (1985) yaitu :

a) Menetapkan siapa yang akan di wawancarai 
Sebelum turun ke lokasi penelitian, peneliti mengadakan studi dokumen dalam hal ini untuk menentukan responden yang akan dijadikan informan sesuai dengan fokus penelitian yang ingin diteliti. Dalam hal ini peneliti harus jeli dan bijaksana dalam menentukan calon informan agar supaya wawancara dapat dilakukan secara efisien dan efektif dalam menjawab permasalahan dalam penelitian ini.

b) Menyiapkan pokok-pokok masalah

Setelah diadakan penetapan calon yang akan diwawancarai, maka pokok-pokok masalah yang akan ditanyakan atau dibicarakan sudah dapat dipersiapkan dan ditulis pada pedoman wawancara yang akan dibawah oleh peneliti untuk memudahkan

peneliti dalam menformulasi agar wawancara itu terarah dan dapat menggali permasalahan yang ada dilapangan.

c) Membuka/mengawali alur pembicaraan Pada saat membuka wawancara peneliti terlebih daulu mengucapkan salam dan memperkenalkan diri serta berusaha menciptakan keadaan yang rileks dan akrab sehingga calon informan tidak merasa terganggu atau tertekan agar supaya informan mau diajak untuk berdialog dan wawancara didahului dengan hal-hal umum dan setelah kontak atau hubungan baik sudah tecipta kemudian mengarahkan dialog ke fokus pemasalahan dalam penelitian.

d) Melangsungkan arus pembicaraan

Peneliti dalam hal ini harus menempatkan diri pada posisi yang banyak tidak mengetahui sehingga banyak mengajukan pertanyaan yang terinci bahkan kalau dirasa kurang perlu mengadakan pengulangan pada pokok-pokok jawaban yang teaa karena akan diadakan analisis.

e) Mengkonfirmasikan dan mengakhiri wawancara

Hasil wawancara perlu dikonfirmasikan kepada sumber informan jika ada hal-hal yang perlu ditambakan atau dipertegas oleh informan. Untuk itu sebelum wawancara diakhiri peneliti perlu membuat resume hasil wawancara dan mengecek kesesuai kepada informan.
Dalam penelitian ini sering terjadi peneliti bolak-balik kepada informan untuk menanyakan atau menyesuaikan hasil wawancara dengan informan lain jika dianggap perlu dikonfirmasikan kembali dan mengadakan wawancara agar mendapatkan informasi sesuai dengan fokuus permasalahan yang sementara diteliti.

f) Menuliskan hasil wawancara

Pada saat wawancara berlangsung, peneliti mencatat hal-hal pokok sesuai

dengan hasil wawancara yang disampaikan oleh informan pada kertas catatan yang disiapkan. Dan catatan itu belum begitu lengkap karena hanya mengandung hal-hal pokok oleh sebab itu sesampainya di rumah perlu

diadakan pembenahan dan penyempurnaan hasil wawancara untuk membuat catatan lapangan.

g) Mengidentifikasi tindak lanjut

Dari hasil wawancara oleh peneliti, maka perlu diidentifikasi pokok-pokok permasalahan yang terangkat dalam wawancara mana yang perlu ditindak lanjuti apakah perlu mengadakan observasi kembali pada sasaran atau wawancara kepada informan lain untuk meyakinkan peneliti bahwa informasi yang didapat oleh peneliti telah menjawab permasalahan sesuai dengan fokus penelitian.

\section{Studi Dokumentasi}

Dalam penelitian kualitatif sumber data utama diperoleh dari manusia melalui observasi dan wawancara selain itu ada juga sumber data yang diperoleh dari dokumendokumen baik itu dokumen secara resmi maupun secara tidak resmi dalam hal ini catatan-catatan pribadi yang dianggap dapat menjadi sumber informasi bagi peneliti.

Dalam studi dokumen ini, peneliti mengadakan penelitian pada dokumendokumen baik berupa formulir-formulir, foto-foto dan bahan-bahan statistik yang berhubungan fokus penelitian yang ada di Kantor Samsat Provinsi Sulawesi Utara yang menjadi sasaran penelitian. 


\section{Metode Analisis Data}

1. Demografis, ekonomi dan sosial budayanya. Gambaran mengenai efektivitas penerimaan pajak ikut ditampilkan oleh peneliti sebagai upaya untuk lebih memahami tentang seluk beluk dari proses tersebut.

2. Setelah tahapan deskriptif selesai dilakukan, kemudian peneliti membangun sebuah tema berdasarkan sejumlah kecil masalah-masalah (sub-kasus) yang diperoleh dari pengumpulan data baik melalui wawancara mendalam, pengamatan berpartisipasi maupun studi dokumentasi. Tahap pertama, peneliti mengidentifikasi permasalahan dan kompleksitas dari masing-masing sub-kasus yang ada. Tahap kedua, peneliti membuat tema pada setiap sub-kasus yang ada untuk menemukan tema secara umum. Setelah analisis tema selesai dilakukan, maka diberikan penegasan (assertion) atau penafsiran mengenai makna dari kasus berdasarkan tema yang ada.

3. Berpijak pada sub-kasus yang telah dirangkum dalam sebuah tema yang telah ada, kemudian peneliti memberikan makna terhadap data tersebut. Data yang telah dimaknai kemudian dihubungkan dengan dengan pendapat ahli, teori, serta penelitianpenelitian sebelumnya. Data yang telah dideskripsikan, diklasifikasikan, dan ditafsirkan selanjutnya disajikan dan divisualisasikan dengan pemodelan sebagai bentuk abstraksi dari data hasil penelitian.

\section{HASIL DAN PEMBAHASAN}

\section{Gambaran Umum Lokasi Penelitian}

Samsat merupakan suatu sistem kerjasama secara terpadu antara Polri, Dinas Pendapatan Provinsi, dan PT Jasa Raharja (Persero) dalam pelayanan untuk menerbitkan STNK dan Tanda Nomor Kendaraan Bermotor yang dikaitkan dengan pemasukan uang ke kas negara baik melalui Pajak Kendaraan Bermotor (PKB), Bea Balik Nama Kendaraan Bermotor, dan Sumbangan Wajib Dana Kecelakaan Lalu Lintas Jalan (SWDKLLJ), dan dilaksanakan pada satu kantor yang dinamakan "Kantor Bersama Samsat".
Lokasi Kantor Samsat umumnya berada di lingkungan Kantor Polri setempat, atau di lingkungan Satlantas/Ditlantas Polda setempat. Samsat ada di masing-masing provinsi, serta memiliki unit pelayanan di setiap kabupaten/kota.

Polri memiliki fungsi penerbitan STNK; Dinas Pendapatan Provinsi menetapkan besarnya Pajak Kendaraan Bermotor (PKB) dan Bea Balik Nama Kendaraan Bermotor (BBN$\mathrm{KB}$ ); sedangkan PT Jasa Raharja mengelola Sumbangan Wajib Dana Kecelakaan Lalu Lintas Jalan (SWDKLLJ).

Proses perpanjang STNK harus membuang waktu cukup lama karena mesti mendatangi tiga kantor. Membayar pajak harus datang ke kantor pajak. Mereka yang hendak membayar Sumbangan Wajib Dana Kecelakaan Lalu Lintas Jalan (SWDKLLJ) dan harus mendatangi kantor Asuransi Jasa Raharja. Kemudian mereka harus mendatangi kantor polisi lalu lintas untuk memperoleh STNK.

Berdasarkan INBERS 3 Menteri, Menhankam, Menkeu dan Mendagri No. Pol.

KEP/13/XII/1976, No. KEP1693/MK/IV/12/1976, 311 TAHUN 1976 bahwa Konsep SAMSAT diberlakukan di seluruh Indonesia Kepolisian RI, PT Jasa Raharja (Persero) dan Dinas Pendapatan Provinsi bersama-sama. Meski demikian masing-masing instansi menerbitkan tanda bukti untuk setiap pelunasan kewajiban di SAMSAT.

Pedoman/Petunjuk Pelaksanaan Sistem Administrasi Manunggal Dibawah Satu Atap dalam pengeluaran STNK, Pembayaran PKB/BBNKB, SWDKLLJ yang dituangkan dalam Surat Edaran Menteri Dalam Negeri No. 16 Tahun 1977 tanggal 28 Juni 1977

Berdasarkan INBERS, Menhankam, Menkeu dan Mendagri No. INS/03/X/1988, No. 5/IMK.013/1988, No. 13A Tahun 1988 dilakukan penyederhanaan dokumen yaitu Formulir permohonan/ pendaftaran STNK/ Pajak/ SWDKLLJ digabung jadi satu.

Tanda Pelunasan Pembayaran SWDKLLJ PT Jasa Raharja (Persero) yang tercantum dalam STNK/STCK berlaku sebagai pengganti polis Asuransi (sertifikat) Diberlakukan revisi masa berlaku STNK dan TNKB dari 1 tahun 
menjadi 5 tahun namun setiap tahunnya melakukan pengesahan STNK berdasarkan INBERS Panglima Angatan Bersenjata, Menkeu dan Mendagri No. INS/02/II/ 1993, No. 01/ IMK. 01/ 1993, No.2A Tahun 1993. Mekanisme Perpanjangan STNK dibentuk 5 pokja (loket) untuk pelayanan.

Berdasarkan INBERS Menhankam, Menkeu dan Mendagri No. Pol. INS/03/M/X/1999, No. 6/IMK.014/1999, No. 29 Tahun 1999 menetapkan penyempurnaan dan penyederhanaan sistem operasi pelayanan dari 5 loket menjadi 2 loket.

Pembayaran SWDKLLJ yang tertera pada SKPD berfungsi sebagai pengganti polis asuransi (sertifikat).

Tanda Pelunasan dan Pengesahan digabung dengan Surat Ketetapan Pajak Daerah (SKPD) yang telah divalidasi cash register sebagai tanda bukti pembayaran.

Dinas Pendapatan Daerah Provinsi Sulawesi Utara dibentuk pada Tahun 1962 dengan nama Kantor Pajak, yang saat itu merupakan bagian dari pemerintahan Daerah Tingkat 1 Sulawesi Utara-Tengah. Pada tahun 1964 seiring dengan terbentuknya Daerah Tingkat 1 Sulawesi Utara dan perkembangan organisasi, berubah menjadi Kantor Inspeksi Pajak.

Dengan ditetapkannya Undang-Undang Nomor 18 tahun 1997 tentang Pajak Daerah dan Retribusi Daerah maka Dinas Pajak dan Pendapatan mengelola 3 jenis pajak daerah yaitu pajak kendaraan bermotor, bea balik nama kendaraan bermotor, pajak bahan bakar kendaraan bermotor dan retribusi daerah. Pada tahun 2000 dengan ditetapkannya UndangUndang nomor 34 tahun 2000 tentang Perubahan atas Undang-Undang nomor 18 tahun 1997 tentang Pajak Daerah dan Retribusi Daerah maka jenis pajak daerah dan retribusi daerah yang yang dikelola Dinas Pajak dan Pendapatan, terdiri atas : Pajak Pengambilan dan Pemanfaatan Air Bawah Tanah dan Air Permukaan, Bea Balik nama Kendaraan di Atas Air, Pajak Kendaraan di Atas Air, Pajak Kendaraan Bermotor, Bea Balik Nama Kendaraan Bermotor, Retribusi Pergantian Biaya Cetak Peta dan Pelayanan Jasa Ketatausahaan. Pada tahun ini juga terjadi pemekaran wilayah Provinsi Gorontalo dengan ditetapkannya Undang-Undang nomor 28 tahun 2000, sehingga wilayah Provinsi Sulawesi Utara meliputi: Kabupaten Sangihe dan Talaud, Kabupaten Minahasa, Kabupaten Bolaang Mongondow, Kota Manado dan Kota Bitung. Hal ini juga mengakibatkan cakupan wilayah UPTD Dinas Pajak dan Pendapatan menjadi berkurang. Pada tahun 2003 Dinas Pajak dan Pendapatan diganti menjadi Dinas Pendapatan berdasarkan Peraturan Daerah nomor 23 tahun 2003. Saat itu Dinas Pendapatan disamping memiliki 5 UPTD juga memiliki 4 Kantor Samsat Pembantu. Yaitu Amurang, Airmadidi, Tomohon dan Talaud, seiring dengan terbentuknya daerah otonomi Kabupaten Minahasa Selatan, Kabupaten Minahasa Utara, Kota Tomohon dan Kabupaten Kepulauan Talaud.

Pada tahun 2008 dengan ditetapkannya Peraturan Pemerintah nomor 41 tahun 2008 tentang Organisasi Perangkat Daerah, maka Dinas Pendapatan menjadi Dinas Pendapatan Daerah berdasarkan Peraturan Daerah Provinsi Sulawesi Utara nomor 3 tahun 2008 tentang Organisasi dan Tata Kerja Dinas Daerah Provinsi Sulawesi Utara. pada tahun tersebut, Kantor Samsat Pembantu Amurang, Airmadidi dan Tomohon ditetapkan menjadi UPTD sehingga Dinas Pendapatan Daerah memiliki 8 UPTD.

Pada tahun tersebut dengan ditetapkannya Undang-Undang nomor 28 tahun 2009 tentang Pajak Daerah dan Retribusi Daerah, maka jenis pajak daerah yang dikelola Dinas Pendapatan Daerah menjadi 5 jenis, yaitu Pajak Kendaraan Bermotor, Bea Balik Nama Kendaraan Bermotor, Pajak Bahan Bakar Kendaraan Bermotor, Pajak Air Permukaan dan Pajak Rokok dan sesuai Undang-Undang, pajak rokok diberlakukan pada tahun 2004.

Pada tahun 2011 ditetapkan lagi 7 UPTD baru, yaitu Talaud, Sitaro, Bolmong, Mitra, Boltim, Bolsel dan Bolmut seiring dengan berdirinya daerah otonom baru di Provinsi Sulawesi Utara sehingga Dipenda memiliki 15 UPTD dan 4 Samsat Pembantu. Pada tahun 2017 Dinas Pendapatan Daerah berubah 
menjadi Badan Pengelola Pajak dan Retribusi Daerah( BP2RD), Kepala Badan dipercayakan kepada Olvie Atteng, S.E, M.Si, tepatnya pada tanggal 3 Januari 2016 sampai dengan saat ini.

\section{Tugas Pokok dan Fungsi}

Badan Pengelola Pajak dan Retribusi Daerah Provinsi Sulawesi Utara mempunyai tugas membantu Gubernur dalam melaksanakan penyusunan dan pelaksanaan kebijakan daerah di bidang pengelolaan pajak dan retribusi daerah. Badan Pengelolah Pajak dan Retribusi Daerah (BP2RD) Daerah Provinsi Sulawesi Utara dalam melaksanakan tugas menyelenggaraan fungsi:

a. Perumusan kebijakan teknis di bidangnya.

b. Penyelenggaraan perencanaan, pengordinasian pengembangan pendapatan daerah.

c. Penyelenggaraan urusan pajak dan retribusi daerah.

d. Penyelenggaraan pangendalian dan pembinaan pendapatan daerah.

e. Penyelenggaraan urusan pemerintahan dan pelayanan umum di bidang pengelolaan pajak dan retribusi daerah.

f. Pelaksanaan tugas lain yang diberikan oleh Gubernur.

\section{Karakteristik Informan}

Informan penelitian berjumlah 10 orang dan memiliki karakteristik yang berbeda sehingga perlu dijelaskan melalui beberapa kategori yaitu pendidikan, jenis kelamin, umur, agama dan status perkawinan serta pekerjaan informan.

\section{Informan menurut Jenis Kelamin}

Tabel 1 menunjukan bahwa Jenis kelamin menunjukkan bahwa informan lakilaki sebanyak 6 orang atau $60 \%$ dan informan permpuan sebanyak 4 orang atau $40 \%$ dari keseluruhannya.

Tabel 1. Jumlah Berdasarkan Jenis Kelamin Informan

\begin{tabular}{llll}
\hline No. & Jenis Kelamin & Frekuensi & Persentase \\
\hline 1. & Laki-laki & 6 & 60 \\
2. & Perempuan & 4 & 40 \\
\hline Jumlah & 10 & 100 \\
\hline
\end{tabular}

Sumber: Hasil Analisis Data 2018

\section{Informan menurut Umur}

Tabel 2 menunjukkan bahwa umur informan $<24$ sebanyak 1 orang atau $10 \%$, dan umur antara 25 sampai 41 tahun sebanyak 2 orang atau $20 \%$ dan umur 42 sampai 48 tahun sebanyak 4 orang atau $40 \%$ serta informan yang berumur $>49$ sebanyak 3 orang atau $30 \%$.

Tabel 2. Umur Informan

\begin{tabular}{llll}
\hline No. & Umur & Frekuensi & Persentase \\
\hline 1. & $<24$ & 1 & 10 \\
2. & $25-41$ & 2 & 20 \\
3. & $42-48$ & 4 & 40 \\
4. & $>49$ & 3 & 30 \\
\hline \multicolumn{2}{l}{ Jumlah } & 10 & 100 \\
\hline
\end{tabular}

Sumber: Hasil Analisis Data 2018

Informan menurut Tingkat Pendidikan Tabel 3 menunjukkan bahwa jumlah

informan yang berpendidikan Sekolah Menengah Atas / SMA sebanyak 5 orang atau $50 \%$, Strata Satu /S1 sebanyak 3 orang atau $30 \%$, dan Strata Dua / S2 sebanyak 2 orang $20 \%$ serta Strata Tiga / S3 belum ada dari keseluruhan informan.

Tabel 3. Pendidikan Informan

\begin{tabular}{llll}
\hline No. & Pendidikan & Frekuensi & Persentase \\
\hline 1. & SMA & 5 & 50 \\
2. & S1 & 3 & 30 \\
3. & S2 & 2 & 20 \\
4. & S3 & - & - \\
\hline \multicolumn{2}{l}{ Jumlah } & 10 & 100 \\
\hline
\end{tabular}

Sumber: Hasil Analisis Data 2018

\section{Informan menurut Jenis Pekerjaan}

Berdasarkan Tabel 4. menunjukkan bahwa informan yang bekerja sebagai Pegawai Negeri Sipil (PNS) sebanyak 6 orang atau 60\% tenaga honorer 1 orang atau $10 \%$ dan swasta sebanyak 2 orang atau $20 \%$ serta pengusaha 1 orang informan atau $10 \%$.

\section{Tabel 4. Pekerjaan Informan}

\begin{tabular}{llll}
\hline No. & Pekerjaan & Frekuensi & Persentase \\
\hline 1. & PNS/ANS & 6 & 60 \\
2. & Honorer & 1 & 10 \\
3. & Swasta & 2 & 20 \\
4. & Pengusaha & 1 & 10 \\
\hline Jumlah & 10 & 100
\end{tabular}

Sumber: Hasil Analisis Data 2018 


\section{Efektivitas Pemungutan Pajak}

Berdasarkan penelitian yang dilakukan yang difokuskan pada penerimaan pajak kendaraan bermotor, penerimaan bea balik nama kendaraan bermotor, kesadaran wajib pajak dan kepatuhan wajib pajak, maka diperoleh hasil bahwa efektivitas pemungutan pajak Kendaraan Bermotor dan Bea Balik Nama Kendaraan Bermotor di BP2RD Provinsi Sulawesi Utara dipengaruhi oleh beberapa aspek, yaitu sumber daya manusia yang ada di BP2RD Provinsi Sulawesi Utara, diseminasi informasi, jarak, waktu, tempat, kondisi sosial, budaya, ekonomi dan pribadi dari wajib pajak.

\section{Penerimaan Pajak Kendaraan Bermotor dan Bea Balik Nama Kendaraan Bermotor}

Penerimaan Pajak Kendaraan Bermotor dan Bea Balik Nama Kendaraan Bermotor merupakan salah satu cara untuk mengetahui efektivitas sebuah pemungutan pajak. Penerimaan Pajak Kendaraan Bermotor dan Bea Balik Nama Kendaraan dapat dilihat dari indikator antara target yang ditetapkan dengan realisasi yang dicapai dalam sebuah periode tertentu. Melalui indikator-indikator tersebut maka efektivitas dalam pemungutan Pajak Kendaraan Bermotor dan Bea Balik Nama Kendaraan Bermotor dapat terlihat.

Dalam meningkatkan penerimaan melalui pemungutan Pajak Kendaraan Bermotor dan Bea Balik Nama Kendaraan Bermotor, maka BP2RD Provinsi Sulawesi Utara telah membuat sebuah strategi dalam upaya merealisasikan target yang telah ditetapkan sebelumnya. Informan Sekretaris Badan BP2RD Provinsi Sulawesi Utara mengungkapkan bahwa "Pada tahap input, pertama yaitu menyangkut dokumen perencanaannya yang di dalamnya terdapat berbagai strategi-strategi di mana bisa mempengaruhi hal-hal yang menyangkut realisasi. Input kedua adalah sumber daya manusia dan input ketiga adalah peralatanperalatannya. Kemudian melalui dari proses kita mulai dari mengidentifikasi permasalahan-permasalahan lalu kita menyusun strategi bagaimana penyelesaian masalahnya serta solusinya. Dari prosesproses itu kita bisa dapat outputnya. Outputnya sesuai dengan indikator kinerja utama yang sudah ditetapkan selama 5 tahun, output yang diharapkan adalah kendaraan yang lunas pajak semakin banyak."

1. Efektifitas Pemungutan Pajak Kendaraan Bermotor Provinsi Sulawesi Utara

Tabel 5 menunjukkan bahwa tigkat efektivitas pemungutan Pajak Kendaraan Bermotor (PKB) berfluktuasi dari tahun 2013 sampai dengan tahun 2017. Pada tahun 2013 tingkat efektivitas pemungutan Pajak Kendaran Bermotor (PKB) adalah sebesar $112,11 \%$ dengan kriteria sangat efektif. Kemudia pada tahun 2014 tingkat efektivitas pemungutan Pajak Kendaraan Bermotor (PKB) mengalami peningkatan sebesar $0,98 \%$ sehingga menjadi $13,09 \%$ dengan kriteria sangat efektif.

\begin{tabular}{|c|c|c|c|c|}
\hline \multicolumn{5}{|c|}{ Provinsi Sulawesi Utara TAHUN 2013-2017 } \\
\hline Tahun & Target (Rp) & Realisasi (Rp) & $\begin{array}{l}\text { Tingkat } \\
\text { Efestivitaa }\end{array}$ & Kriteria \\
\hline 2013 & 154.080 .000 .000 & 172.734 .891 .451 & $112,11 \%$ & Sangat Efektif \\
\hline 2014 & 183.056 .000 .000 & 207.015 .219 .500 & $113,09 \%$ & SangatEfektif \\
\hline 2015 & $225,725.867 .000$ & $231,868.053,395$ & $102,72 \%$ & Sangat Efektif \\
\hline 2016 & 253.475 .048 .000 & 275.640 .090 .918 & $108,06 \%$ & Sangat Efelatif \\
\hline 2017 & 311.435 .000 .000 & 330.312 .328 .813 & $108.54 \%$ & Sangzat Efektif \\
\hline
\end{tabular}

Sumber Data : Diolah Sendin

Namun pada tahun 2015 efektivitas pemungutan Pajak Kendaraan Bermotor (PKB) mengalami penurunan yang sangat rendah sebesar $10,37 \%$ sehingga menjadi $102,72 \%$ walaupun dengan kriteria sangat efektif. Pada tahun 2016 tingkat efektivitas pemungutan Pajak Kendaraan Bermotor (PKB) kembali mengalami peningkatan dari tahun 2016 yaitu sebesar 6,02\% sehingga menjadi $108,74 \%$ dengan kriteria sangat efektif. Dan pada tahun 2017 tingkat efektivitas pemungutan Pajak Kendaraan Bermotor (PKB) mengalami penurunan yang cukup rendah sebesar $2,68 \%$ sehingga menjadi $106,06 \%$ tetap dengan kriteria sangat efektif. 


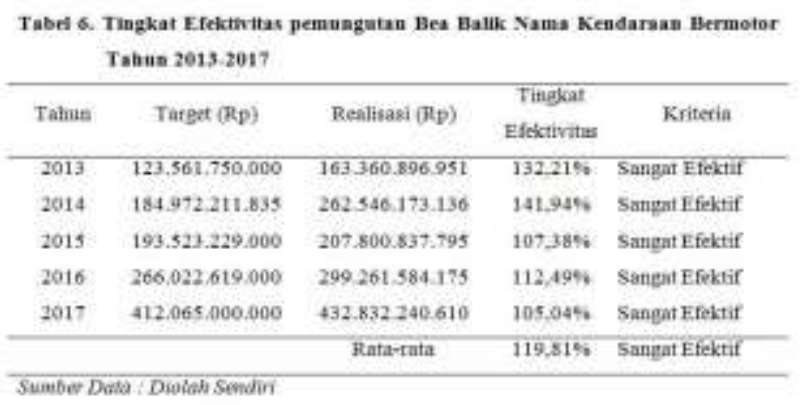

Tabel 6 menunjukkan bahwa tigkat efektivitas pemungutan Bea Balik Nama Kendaraan Bermotor (BBNKB) berfluktuasi dari tahun 2013 sampai dengan tahun 2017. Pada tahun 2013 tingkat efektivitas pemungutan Bea Balik Nama Kendaraan Bermotor (BBNKB) adalah sebesar 132,21\% dengan kriteria sangat efektif. Selanjuanya pada tahun 2014 tingkat efetivitas pemungutan Bea Balik

Nama Kendaraan Bermotor (BBNKB) mengalami peningkatan yang cukup besar yaitu sebesar 9,73\% sehingga menjadi 141,94\% dengan kriteria sangat efektif. Namun pada tahun 2015 tingkat efektivitas pemungutan Bea Balik Nama Kendaraan Bermotor (BBNKB) mengalami penurunan yang sangat rendah sebesar $34,56 \%$ sehingga menjadi 107,38\% walaupu dengan kriteria sangat efektif. Pada tahun 2016 tingkat efektivitas pemungutan Bea Balik Nama Kendaraan Bermotor (BBNKB) kembali mengalami peningkatan dari tahun 2015 yaitu sebesar $5,11 \%$ sehingga menjadi $112,49 \%$ dengan kriteria sangat efektif. Namun pada tahun 2017 tingkat efektivitas pemungutan Bea Balik Nama Kendaraan Bermotor (BBNKB) mengalami penurunan yang cukup rendah yaitu sebesar $7,45 \%$ sehingga menjadi $105,04 \%$ tetap dengan kriteria sangat efektif.

Bedasarkan perhitung bahwa selama lima tahun terakhir tingkat efektivitas pemungutan Bea Balik Nama Kendaraan Bermotor (BBNKB) adalah sangat efektif,

dengan rata-rata tingkat efektivitas pemungutan per tahunnya sebesar $119,81 \%$. Dibandingkan dari pemungutan Pajak Kendaraan Bermotor (PKB) ternyata tingkat efektivitas pemungutan Bea Balik Nama Kendaraan Bermotor (BBNKB) lebih tinggi sehingga sangat efektif sekali, hal ini dapat dilihat dari rata-rata tingkat efektivitas pemungutan pajak pertahunnya.

\section{Kesadaran wajib pajak}

Efektivitas sebuah pemungutan Pajak Kendaraan Bermotor dan Bea Balik Nama Kendaraan Bermotor salah satunya ditentukan oleh faktor kesadaran dari wajib pajak. Kesadaran wajib pajak dapat dilihat dari indikator pengetahuan masyarakat mengenai pajak, pemahaman terhadap isi dan aturan untuk membayar pajak, sikap masyarakat dalam membayar pajak. Melalui indikatorindikator tersebut maka efektivitas dalam pemungutan Pajak Kendaraan Bermotor dan Bea Balik Nama Kendaraan Bermotor dapat terlihat.

Menurut Sidik dalam Ikhsan dan Salomo (2002), tax effectiveness tidak lain merupakan perbandingan antara penerimaan pajak aktual (penerimaan pajak yang sebenarnya, aktual yield). Ukuran efektivitas pemungutan pajak daerah ini pada dasarnya dapat digunakan untuk menganalisis efektivitas pemungutan pajak secara nasional, seperti total penerimaan pajak nasional, total penerimaan jenis pajak secara nasional, total penerimaan pajak regional serta total penerimaan pajak secara regional. Secara oprasional efektivitas pajak dapat dihitung dengan mengunakan rumus Tax perfomance index (TPI), yakni hasil bagi antara realisasi penerimaan pajak dengan target penerimaan pajak. Semakin besarnya angka TPI menunjukkan semakin efektifnya pemungutan pajak dikaitkan dengan sasaran atau target yang akan diperoleh. Beberapa kegiatan dalam administrasi perpajakan daerah yang perlu dianalisis perfomancenya dalam rangka penerimaan pajak daerah diantaranya adalah pencairan tunggakan, penetapan, penerapan sanksi, pemeriksaan, pengusutan, penagihan dan collection ratio. Untuk itu diperlukan suatu pendekatan identifikasi potensi setiap jenis pajak agar kebijakan collection ratio tidak hanya sesuai dengan potensi pajak namun juga dapat direalisasikan melalui

penerapan suatu sistem manajemen pengelolaan sumber-sumber penerimaan pajak. Dalam konteks ini, menurut Sumitro dalam Munawir (1998), pajak ialah iuran rakyat kepada kas negara (peralihan kekayaan dari sektor partikelir ke sektor pemerintah) 
berdasarkan undang-undang (dapat dipaksakan) dengan tidak mendapat jasa timbal balik (tegen prestise) dari negara yang langsung dapat ditunjuk dan yang digunakan untuk membiayai pengeluaran umum (publik uitgaven).

Bila ditinjau dari sisi kinerja pengelolaan pajak, menurut Smeets (dalam Pudyamiko, 2002), pajak merupakan prestasi kepada pemerintah yang terutang melalui norma-norma hukum dan yang dapat dipaksakan, tanpa adanya kontraprestasi yang dapat ditunjukan dalam hal individual, maksudnya adalah untuk membiayai pengeluaran pemerintah. Pandangan Smeets ini menonjolkan adanya fungsi budgeter dari pajak, yakni untuk memasukan uang ke kas Negara.

Karena itu, pemungutan pajak harus dilakukan secara efektif. Dalam konteks ini, Sidik (dalam Ikhsan dan Salomo, 2002) menjelaskan "Tax Effectiveness secara tidak langsung juga menunjukan seberapa besar keberhasilan daerah dalam mengumpulkan pajak dari potensi yang dimilikinya. Semakin kecil selisih antara penerimaan pajak yang sebenarnya dengan potensi pajak yang ada maka berarti semakin efektiflah administrasi perpajakan daerah. hal tersebut juga meninjukan bahwa semua potensi pajak yang ada dapat dipungut seluruhnya. Selain itu tingginya angka tax effectiveness juga menunjukan kecilnya tunggakan pajak dan penghindaran pajak oleh si wajib pajak.

Ukuran untuk menilai kemampuan administrasi perpajak dalam menggali dan merealisasikan potensi penerimaan pajak yang ada dinamakan dengan rasio efisiensi administrasif (administrasive efficiency ratio atau AER). Pengukuran potensi pajak dengan menggunakan AER tersebut dapat di terapkan baik dari segi penerimaan, dari segi jumlah wajib pajak, maupun dari segi objek pajak".

Dengan memahami faktor-faktor yang mempengaruhi efektivitas pemungutan pajak itu, maka setiap daerah harus cermat dalam memberlakukan kebijakan perpajakan. Dalam hal ini Davey (1988), mengatakan beberapa hal Pemerintah Regional dibenarkan oleh undang-undang atau peraturan memungut, menaksir atau mengumpulkan pajak pendapatan, bersifat pararel akan tetapi berbeda dengan pajak pendapatan nasional. Secara keseluruhan pembagian administrasi pajak dan perhitungan yang dipakai atas kekayaan di daerah tidak sama dengan pengenaan, pembebasan atau keringanan yang diberikan kepada perorangan untuk tingkat nasional.

Menurut Informan Staf Bidang Pajak Daerah BP2RD Provinsi Sulawesi Utara "Masih ada yang kurang mengerti pada saat membeli kendaraan. Sebenarnya harus dijelaskan kepada mereka tentang kewajiban yang harus dipenuhi. Balik nama pertama saat membeli kendaraan dan lalu membayar pajak kendaraan tiap tahun. Mereka masih banyak yang lupa dan masa bodoh. Adakalanya kendaraan mereka sudah rusak tapi tidak dilaporkan untuk dilalukan penghapusan, kalau tidak dilaporkan statusnya masih masuk pada potensi pajak yang harus dipungut. Status pajaknya masih aktif. Alasan yang lain adalah tidak adanya uang. Mereka masih perlu diajak untuk mengatur keuangan supaya bisa menyisihkan pembayaran pajak. Harus ada pendekatan yang lain lagi."

Masih banyak masyarakat wajib pajak yang sepertinya belum mengerti sepenuhnya terkait periodisasi pembayaran Pajak Kendaraan bermotor dan Bea Balik Nama Kendaraan Bermotor. Meskipun demikian, tidak dipungkiri bahwa kesadaran wajib selalu memiliki hubungan yang erat dengan kondisi keuangan yang dimiliki oleh wajib pajak. Seperti yang dikatakan oleh Informan Sekretaris Badan BP2RD Provinsi Sulawesi Utara. "Kemungkinan besar yang sering terjadi dalam konteks attitude wajib pajak. Seperti halnya ada yang belum mengerti apakah pajak harus dibayar setiap tahun, lalu soal tidak adanya uang ketika periode untuk membayar pajak." Menurut Informan

Kasubag Kepegawaian dan Hukum, sosialisasi perlu dilakukan agar menggugah kesadaran dari wajib pajak dalam membayar pajaknya kepada pemerintah, di mana diperlukan juga kemampuan personil dalam 
melakukan sosialisasi tersebut. "Setiap personil butuh bagaimana memberikan sosialisasi dan memberitahukan info kepada masyarakat. Kemampuan personalia sangat berperan. Kemampuan dalam berkomunikasi juga perlu dimiliki, karena disini kita akan memberitahukan hutangnya kepada pemerintah. Strategi kita harus tahu kompetensi dari pegawai sendiri, harus tahu kemampuan dan pengalamannya. Di kantor pusat uraian kita terdapat dalam Pergub 100 dan 81 tahun 2016."

Hal tersebut diperkuat oleh pernyataan oleh Informan Kepala Badan BP2RD Provinsi Sulawesi Utara bahwa selain sosialisasi merupakan sesutu yang penting untuk dilakukan di samping penyedian sarana dan prasarana. Untuk penyediaan sarana dan prasarana BP2RD Provinsi Sulawesi Utara mengembangkan sistem yang berbasis teknologi, dan melakukan penambahan unit pelayanan yang bervariasi, ada yang statis dan ada pula yang mobile. Sementara itu, sosialisasi dilakukan kepada masyarakat sampai titik desa. Itu adalah strategi dari BP2RD Provinsi Sulawesi Utara. Kendaraan di air juga masuk, walaupun ada kategori knotnya. Kalau itu sudah urusan kementrian. Sosialisasi dilakukan dalam banyak bentuk, ada yang langsung pada masyarakat, lewat media dan dunia maya, brosur di unit-unit pelayanan dan lain-lain. BP2RD Provinsi Sulawesi Utara memiliki pelayanan standard yang selalu dilakukan, ada 36 sampai 40 komponen dalam memenuhi itu oleh Ombudsman.

\section{Kepatuhan wajib pajak}

Kepatuhan dari wajib pajak dalam membayar sangat menentukan efektivitas pemungutan Pajak Kendaraan Bermotor dan Bea Balik Nama Kendaraan Bermotor. Kepatuhan wajib pajak dapat dilihat dari indikator ketepatan waktu pelaporan pajak serta pembayaran pajak sebelum jatuh tempo. Melalui indikator-indikator tersebut maka

efektivitas dalam pemungutan Pajak Kendaraan Bermotor dan Bea Balik Nama Kendaraan Bermotor dapat terlihat.
Terdapat beberapa alasan dari wajib pajak yang patuh dalam membayar Pajak Kendaraan Bermotor dan Bea Balik Nama Kendaraan Bermotor. Untuk menghindari denda dan menghindari operasi tilang ketika dalam melakukan perjalanan dengan

menggunakan kendaraan bermotor. Sebagaimana yang diungkapkan oleh Informan wajib pajak Yani, bahwa "Saya membayar Pajak Kendaraan Bermotor dan Bea Balik Nama Kendaraan Bermotor secara tepat waktu agar dalam melakukan perjalan tidak mengalami hambatan di jalan ketika ada operasi kendaraan bermotor yang dilakukan oleh pihak berwenang. Selain itu, agar saya terhindar dari denda karena terlambat membayar."

Hal senada diungkapkan oleh Informan Olvi dan Informan Christina bahwa mereka melakukan pembayaran tepat waktu Pajak Kendaraan Bermotor dan Bea Balik Nama Kendaraan Bermotor agar tidak mengeluarkan uang yang lebih karena dikenai denda jika terlambat melakukan pembayaran, serta untuk menghindari tilang ketika mereka sedang melakukan perjalanan di dalam kota maupun pada saat ke luar kota, terutama apabila sedang melakukan perjalanan bersama keluarga maupun saat melakukan perjalanan tugas. Persoalan tentang jarak, waktu dan faktor human eror merupakan persoalan yang membuat penerimaan Pajak Kendaraan Bermotor dan Bea Balik Nama Kendaraan

Bermotor menjadi belum terealisasi seabagaimana mestinya. Hal ini seperti diungkapkan oleh Informan Sekretaris Badan BP2RD Provinsi Sulawesi Utara. "Ada permasalahan aksesibilitas juga, artinya jarak dari wajib pajak ke tempat unit pembayaran. Dulunya pembayaran terdapat di titik-titik Samsat berada. Itu masalah yang paling krusial saat ini. Adapun tingkat kesulitan wajib pajak untuk datang membayar pajak, misalnya soal waktu. Jika mereka ingin datang membayar tentunya harus mengorbankan jam kerja mereka. Masih banyak yang belum patuh akan kewajibanya untuk membayar pajak. Ada yang lupa juga 
jika harus membayar pajak dan sebagainya. Permasalahan ini yang akan diramu dalam suatu strategi supaya kedepannya bisa ditanggulangi."

Terdapat beberapa permasalahan yang membuat masih adanya tidak membayar pajak seperti halnya faktor pertumbuhan ekonomi dan besaran pendapatan yang diperoleh masyarakat wajib pajak. Padahal kalau soal kepatuhan hal itu sudah seharusnya dilakukan. Karena notabennya mereka yang wajib pajak tentu memilki kendaraan bermotor dan memiliki pekerjaan serta tidak dikategorikan sebagai orang miskin karena mampu membeli.

Permasalahan ini yang akan diramu dalam suatu strategi supaya kedepannya bisa ditanggulangi. Di sisi lain kita dikejar target supaya yang membayar pajak di atas $60 \%$ diluar kendaraan baru. Kendaraan baru yang ditargetkan adalah 7\%. Dari segi individu, kelompok dan organisasi permasalahanpermasalahan yang ada, yaitu kita memerlukan sumber daya manusia yang mampu melakukan perencanaan perpajakan, penelusuran dan penagihan, melayani wajib pajak yang datang untuk membayar, dari faktor organisasi dia harus mampu bekerja sama dengan pihak lain terutama kepolisian, Jasa Raharja dan Perbankan Bank Sulut Go.

Persoalan sosial, budaya dan ekonomi, juga sudah disinggung tadi. Soal sosial bagaimana kesadaran masyarakat untuk membayar pajak sesuai UU 28. Soal budaya, kalau kita lihat trend saat ini yang paling bermasalah adalah budaya antri. Banyak warga yang tidak bisa melakukan hal itu. Kita akan carikan solusinya juga. Kemudian budaya untuk menjaga fasilitas melalui pajak kendaraan bermotor ini, ada jalan, fasilitas kesehatan dll. Ekonomi masyarakat juga berpengaruh seperti halnya jika ekonomi mereka bertumbuh otomatis kecenderungan untuk membayar pajak akan lebih baik lagi. Selain masalah-masalah di atas ada juga soal keterpaduan kerjasama antara kelompok masyarakat yang ada. Hal itu tergambar saat mereka ingin datang membayar. Contohnya ketika datang membayar, prosesnya mereka sudah memenuhi segala persyaratan seperti ada STNK dan KTP. Ada kalanya permasalah yang terjadi, yaitu mengganti

STNK. Hal ini merupakankan urusan kepolisian, kita perlu tahu berapa lama kepolisian akan melayani hal itu dan berapa lama waktu yang diberikan kepada kami pihak perpajakan. Jadi semua pihak harus terintegrasi dalam menangani hal ini, baik kepolisian, jasaraharja dan perpajakan.

Dalam upaya meningkatkan kepatuhan wajib pajak, maka BP2RD Provinsi Sulawesi Utara melakukan beberapa hal dalam meningkatkan pemungutan pajak di antaranya menyusun dokumen perencanaan, merekrut sumber daya manusia yang punya kapabalitas di Bidang Ekonomi dan lain-lain, perencanaan rencana kerja 1 tahun, strategi-strategi, perjanjian kerja sama bersama pihak kepolisian, Jasa Raharja dan sudah melakukan e-samsat online. BP2RD Provinsi Sulawesi Utara sudah berbasis online sekarang. Dulu masyarakat datang membayar pajak hanya di titik ada Samsat (22 titik). Sekarang 2017 kita sudah kembangkan sistem pembayaran di unit-unit pelayanan-pelayanan yang ada Bank Sulut (Teller atau ATM). Dari 22 titik menjadi 370an. Karena sudah termasuk titik-titik Bank Sulut dana Atm Bank Sulut. Kemudahan lainnya masyarakat sudah bisa mengecek besaran pajaknya melalui aplikasi, tidak lagi secara manual seperti dahulu. Semuanya sudah terinci dalam aplikasi. Hal ini dilakukan supaya lebih efektif, modern, transparan. BP2RD Provinsi Sulawesi Utara juga sudah melakukan kerjasama dengan dealer, finance, showroom untuk bisa dilakukan penerangan supaya melakukan wajib pajak setiap tahunnya. Adapun dengan mal-mal, Universitas, Gerejagereja, guna sosialisasi tentang pajak itu sendiri. Yang paling utama dilakukan saat ini adalah bagaimana mendekatkan masyarakat dengan fasilitas-fasilitas bayar pajak itu. Kedepannya kita akan lakukan kerja sama dengan Alfamart, Indomart dan unit-unit pelayanan umum yang ada. Samsat nasional akan diadakan, supaya saat kita ada diluar kota, kita tetap bisa membayar pajak di mana saja.

Solusi untuk mengefektifkan pemungutan pajak adalah meninteksifikasikan pemungutannya. Kami ingin mencarikan 
strategi supaya setiap saat bisa dibagi jadwal untuk melakukan penelusuran. Seperti halnya membawakan surat bahwa sudah dekat jatuh tempo/door to door, selain call center. Razia kendaraan dengan kepolisian dan jasa raharja akan dilakukan lebih intens. Lalu kerjasama kebijakan dengan kepala-kepala daerah dalam hal pembayaran pajak kendaraan dinas. Kedepan kita harus terus mengembangkan

sumber daya manusia dan sarana prasarana/mobile link, karena kita harus melaksanakan pelayanan pemungutan di tempat (samsat deliveri). Dalam hal ini kita perlu berkomitmen pemimpin-pemimpin daerah untuk kebijakan efektifitas pemungutan pajak.

Menurut Norman D. Nowak (Moh. Zain: 2004), Kepatuhan Wajib Pajak memiliki pengertian yaitu Suatu iklim kepatuhan dan kesadaran pemenuhan kewajiban perpajakan, tercermin dalam situasi di mana:

1. Wajib pajak paham atau berusaha untuk memahami semua ketentuan peraturan perundang-undangan perpajakan.

2. Mengisi formulir pajak dengan lengkap dan jelas.

3. Menghitung jumlah pajak yang terutang dengan benar.

4. Membayar pajak yang terutang tepat pada waktunya."

Menurut Erard dan Feinstein yang di kutip oleh Chaizi Nasucha dan di kemukakan kembali oleh Siti Kurnia (2006), pengertian kepatuhan wajib pajak adalah rasa bersalah dan rasa malu, persepsi wajib pajak atas kewajaran dan keadilan beban pajak yang mereka tanggung, dan pengaruh kepuasan terhadap pelayanan pemerintah.

Menurut Safri Nurmanto dalam Siti Kurnia Rahayu (2010), mengatakan bahwa kepatuhan perpajakan dapat didefinisikan sebagai sutau keadaan di mana Wajib Pajak memenuhi semua kewajiban perpajakan dan melaksanakan hak perpajakannya.

Kepatuhan wajib pajak merupakan pemenuhan kewajiban perpajakan yang dilakukan oleh pembayar pajak dalam rangka memberikan kontribusi bagi pembangunan dewasa ini yang diharapkan di dalam pemenuhannya diberikan secara sukarela.
Kepatuhan wajib pajak menjadi aspek penting mengingat sistem perpajakan Indonesia menganut sistem Self Asessment di mana dalam prosesnya secara mutlak memberikan kepercayaan kepada wajib pajak untuk menghitung, membayar dan melapor kewajibannya.

\section{KESIMPULAN DAN SARAN}

bahwa:

\section{Kesimpulan \\ Hasil penelitian ini menunjukkan}

1. Efektivitas Pemungutan Pajak Kendaraan Bermotor dan Bea Balik Nama Kendaraan Bermotor di BP2RD Provinsi Sulawesi Utara adalah sangat efektif sehingga dapat meningkatkan pendapatan Asli Daerah (PAD) Provinsi Sulawesi Utara. Hal ini ditunjukkan dari hasil perhitungan masingmasing jenis pajak daerah provinsi dengan rata-rata persentase melebihi $100 \%$.

2. Kinerja dari Pemungutan Pajak Kendaraan Bermotor dan Bea Balik Nama Kendaraan Bermotor di Badan Pengelolaan Pajak dan Retribusi Daerah (BP2RD) Provinsi Sulawesi Utara, menunjukkan sangat baik karena realisasi melebihi target yang ditentukan.

\section{Saran}

Berdasarkan keefektifan dan kinerja Pemungutan Pajak Kendaraan Bermotor dan Bea Balik Nama Kendaraan Bermotor di Badan Pengelolaan Pajak dan Retribusi Daerah (BP2RD) Provinsi Sulawesi Utara, maka penulis menyarankan bahwa:

1. Mempertahankan dan meningkatkan Efektivitas Pemungutan Pajak Kendaraan Bermotor dan Bea Balik Nama Kendaraan Bermotor di BP2RD Provinsi Sulawesi Utara.

2. Tetap mempertahankan motivasi kinerja Pemungutan Pajak Kendaraan Bermotor dan Bea Balik Nama Kendaraan Bermotor di BP2RD Provinsi Sulawesi Utara agar pencapaian target dapat dipertahankan bahkan lebih dimaksimalkan. 


\section{DAFTAR PUSTAKA}

Amanda, P dan I K. Jati. 2012. Faktor-faktor yang Mempengaruhi Kepatuhan Wajib Pajak Dalam Membayar Pajak Kendaraan Bermotor di Denpasar. E-Jurnal Akuntansi. ojs.unud.ac.id.

Azwar. 2007. Sikap Manusia, Teori dan Pengukurannya. Edisi Ke 2. Pustaka Pelajar. Jakarta.

Elfanta M. F. C. 2014. Pengaruh Pajak Kendaraan Bermotor, Bea Balik Nama Kendaraan Bermotor, dan Pajak Air Permukaan Terhadap Pendapatan Asli Daerah Provinsi Kepulauan Riau. Jurnal. http://jurnal.umrah.ac.id.

Juniati, E. 2013. Analisis Sistem Pengalihan Pajak Kendaraan Bermotor Menjadi Pajak Daerah. Jurnal Akuntansi Unesa. ejournal.unesa.ac.id.

Halim, A. 2004. Manajemen Keuangan Daerah. UPP AMP YKPN. Yogyakarta.

Hardiningsih, P dan R. M. Oktaviani. 2013. Pengaruh Due Professional Care, Etika, dan Tenur Terhadap Kualitas Audit.

Ilyas, B.W dan R. Burton. 2010. Hukum Pajak. Salemba Empat. Jakarta.

Kurniawan, P. dan A. Purwanto. 2006. Pajak Daerah dan Restribusi Daerah di Indonesia. Bayumedia Publishing. Malang.
Mardiasmo. 2011. Perpajakan. Edisi Revisi 2011. Andi. Yogyakarta.

Putra, I. M. A. D dan I. K. Jati. 2017. Analisis Faktor-faktor yang Mempengaruhi Kepatuhan Wajib Pajak Kendaraan Bermotor di Kantor Bersama Samsat Tabanan. Jurnal. E-Jurnal Akuntansi Universitas Udayana Vol.18.1. ojs.unud.ac.id.

Resmi, S. 2011. Perpajakan: Teori dan Kasus. Salemba Empat. Jakarta.

Septiani, A. 2005. Faktor-Faktor yang Mempengaruhi Ketepatwaktuan Pelaporan Keuangan pada Pasar Modal yang sedang Berkembang. Perspektif Teori Pengungkapan. Tesis. Program Pascasarjana Magister Sains Akuntansi. Universitas Dipenogoro. Semarang.

Siahaan, M. P. 2008. Pajak Bumi dan Bangunan di Indonesia. Graha Ilmu.

Tungka, M dan H. Sabijono. 2015. Analisis Perhitungan dan Pencatatan Pajak Kendaraan Bermotor pada Dinas Pendapatan Daerah Provinsi Sulawesi Utara. Jurnal. ejournal.unsrat.ac.id.

Waluyo. 2011. Perpajakan Indonesia. Salemba Empat. Jakarta. 